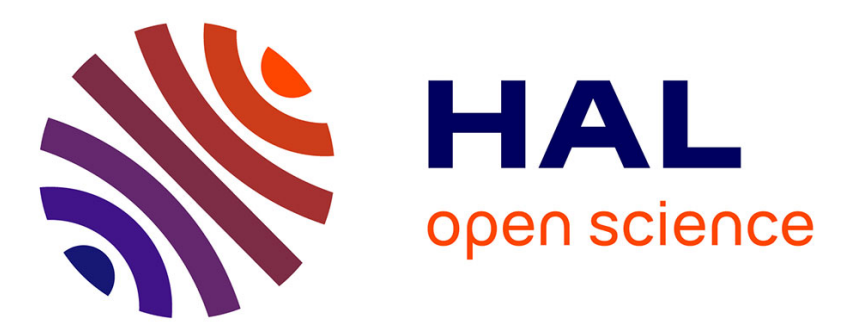

\title{
Tectonic and climatic control of the changes in the sedimentary record of the Karnali River section (Siwaliks of western Nepal).
}

\author{
P. Huyghe, J.L. Mugnier, A.P. Gajurel, Bernard Delcaillau
}

\section{- To cite this version:}

P. Huyghe, J.L. Mugnier, A.P. Gajurel, Bernard Delcaillau. Tectonic and climatic control of the changes in the sedimentary record of the Karnali River section (Siwaliks of western Nepal).. Island Arc, 2005, 14, pp.311-327. 10.1111/j.1440-1738.2005.00500.x . hal-00100385

\section{HAL Id: hal-00100385 \\ https://hal.science/hal-00100385}

Submitted on 26 Sep 2006

HAL is a multi-disciplinary open access archive for the deposit and dissemination of scientific research documents, whether they are published or not. The documents may come from teaching and research institutions in France or abroad, or from public or private research centers.
L'archive ouverte pluridisciplinaire HAL, est destinée au dépôt et à la diffusion de documents scientifiques de niveau recherche, publiés ou non, émanant des établissements d'enseignement et de recherche français ou étrangers, des laboratoires publics ou privés. 


\title{
Tectonic and climatic control of the changes in the sedimentary record of the Karnali River section (Siwaliks of western Nepal)
}

\author{
Pascale Huyghe, ${ }^{1, *}$ JeAN-LOUis MugNier, ${ }^{1}$ ANANTA PRASAd GAJUREL ${ }^{1,2}$ \\ AND BERNARD DELCAILLAU ${ }^{3}$
}

'Laboratoire de Géodynamique des Chaînes Alpines et Université Joseph Fourier, Maison des Géosciences, Grenoble Cedex, France (email: huyghe@ujf-grenoble.fr), 'Department of Geology, Tribhuvan University, Kathmandu, Nepal, and 'Laboratoire de Morphodynamique Continentale et Côtière, Université de Caen, 14032 Caen Cedex, France

\begin{abstract}
A multidisciplinary study was conducted on the section of the Siwalik Group sediments, approximately $5000 \mathrm{~m}$ thick, exposed along the Karnali River. Analysis of facies, clay mineralogy and neodymium isotope compositions revealed significant changes in the sedimentary record, allowing discussion of their tectonic or climatic origin. Two major changes within the sedimentary fill were detected: the change from a meandering to a braided river system at ca $9.5 \mathrm{Ma}$ and the change from a deep sandy braided to a shallow sandy braided river system at ca 6.5 Ma. The 9.5-Ma change in fluvial style is contemporaneous with an abrupt increase of $\sum_{\mathrm{Nd}}(0)$ values following a $\sum_{\mathrm{Nd}}(0)$ minimum. This evolution indicates a change in source material and erosion of Lesser Himalayan rocks within the Karnali catchment basin between 13 and $10 \mathrm{Ma}$. The tectonic activity along the Ramgarh thrust caused this local exhumation. By changing the proximity and morphology of relief, the forward propagation of the basal detachment to the main boundary thrust was responsible for the high gradient and sediment load required for the development of the braided river system. The change from a deep sandy braided to a shallow sandy braided river system at approximately 6.5 Ma was contemporaneous with a change in clay mineralogy towards smectite-/kaolinite-dominant assemblages. As no source rock change and no burial effect are detected at that time, the change in clay mineralogy is interpreted as resulting from differences in environmental conditions. The facies analysis shows abruptly and frequently increasing discharges by 6.5 Ma, and could be linked to an increase in seasonality, induced by intensification of the monsoon climate. The major fluvial changes deciphered along the Karnali section have been recognized from central to western Nepal, although they are diachronous. The change in clay mineralogy towards smectite-/kaolinite-rich assemblages and the slight decrease of $\sum_{\mathrm{Nd}}(0)$ have also been detected in the Bengal Fan sedimentary record, showing the extent and importance of the two major events recorded along the Karnali section.
\end{abstract}

Key words: clay mineralogy, climate, facies analysis, Himalaya, Karnali section, neodymium isotope, Neogene, Siwaliks of Nepal, tectonics.

\section{INTRODUCTION}

Peripheral foreland basins develop in response to the load of thickened crust resulting from continental collision (Beaumont 1981; Allen et al. 1986). The sedimentary infill of foreland basins records the interaction between the growth of the thrust wedge, the isostatic adjustments of the cratonic lithosphere to thrust loading and additional bending moments, eustasy and the surface processes that redistribute material from the mountain belt into the surrounding basins. As a consequence, studying the fill of an ancient setting could serve as a key for the reconstruction of both the growth of the orogen and climate evolution. However, it is increasingly obvious that these two phenomena interact (Molnar \& England 1990) and their own geological signature is very difficult to decipher. Nonetheless, a multidisciplinary study should provide clues to distinguish between these phenomena.

The aim of the present paper was to analyze the major changes in the fill of the Tertiary Himalayan 
Foreland Basin (Siwalik Group in western Nepal) in the light of a pluridisciplinary study and to try to determine their tectonic or climatic origin. Interpretation was mainly based on lithofacies analysis to characterize the fluvial style (hydraulic conditions), $\mathrm{Nd}$ isotope geochemistry as a source marker, and clay mineralogy, which provides information on silicate weathering (Derry \& France- Lanord 1997).

\section{GEOLOGICAL SETTING}

The Siwalik Formations represent the Cenozoic Foreland Basin sequence of the Himalayan Belt. They are located beneath the Gangetic Plain or in the outer part of the fold and thrust belt (DeCelles et al. 1998). The Outer Himalaya, located between the Lesser Himalaya to the north and the Terai Plain to the south (Fig. 1), is usually called the 'Siwalik Belt' and is affected by several thrusts. These thrusts branch off the main decollement, which lies at a depth of 4-5 km beneath the outer belt (Mugnier et al. 1993, 2004; DeCelles et al. 1998; Powers et al. 1998) and roots in the middle crust beneath Tibet (DeCelles et al. 2001). The thrust system of the Himalayan belt is characterized by a general forward propagation of the tectonics, with the activity of the main central thrust (MCT), mainly before 18 Ma (DeCelles et al. 2001), and the main frontal thrust (MFT), which is has been active since 1.8-2.4 Ma (Mugnier et al. 2004). The detail of the thrust sequence is complex and involves numerous out-of-sequence reactivations (Mugnier et al. 1998).

The foreland basin sequence is classically subdivided into three units on the basis of lithostratigraphic criteria (Auden 1935; Rao et al. 1988). These are named the Lower, Middle and Upper Siwaliks and their ages range from Middle Miocene to Pleistocene (Gautam \& Rösler 1999). The Siwalik Group of western Nepal represents a typical fluvial fining upward succession, with the lower unit consisting of fluvial channel sandstones alternating with oxidized calcareous paleosols, the middle unit consisting of very thick channel sandstones and drab-colored histosols, and the upper unit comprising mainly gravely braided river deposits (DeCelles et al. 1998; Nakayama \& Ulak 1999). Although this succession looks like an autogenetic succession in a foreland basin (Miall 1985; Delcaillau 1992), the Himalayan tectonics and the climate of southeast Asia also control the sedimentation (Brozovic \& Burbank 2000); the Siwalik deposition is contemporaneous with the propagation and/or the reactivation of thrust faults and with major climatic events, like the intensification of the Indian monsoon system at ca 8 Ma (Kroon et al. 1991; Prell et al. 1992) or the global Pliocene cooling Molnar \& England 1990; Ravelo et al. 2004). Stable isotope geochemical studies on herbivore tooth enamel, on fossil organic matter and on paleosol carbonates (Quade et al. 1992, 1995) show a dramatic change from forest to tropical grassland and strongly suggest that a major climatic change occurred in the Siwalik Basin at 7-6 Ma throughout the region from Pakistan to Nepal. The Karnali River drains through the Siwaliks in western Nepal (Fig. 1). Its drainage basin has an area of approximately $52000 \mathrm{~km}_{2}$ and it is one of the most important rivers in Nepal. The basin comprises formations belonging to the High Himalaya, Lesser Himalaya and Neogene molasses of the Siwaliks. The Karnali River offers a stratigraphic section approximately $5000 \mathrm{~m}$ thick, representing the complete series from the Lower to the Upper Siwalik Formations (Mugnier et al.1998). The lower 3560-m-thick part of the section has been accurately dated from 15.8 to 5.2 Ma by magnetostratigraphy (Gautam \& Fujiwara 2000), which permitted assigning ages to the various trends and events recorded in the sedimentary succession. For the younger deposits, from the deposits dated at 5.2 Ma to the top, a constant mean sediment accumulation rate of $33 \mathrm{~cm} / \mathrm{ky}$ was adapted for the present study (Gautam \& Fujiwara 2000).

\section{SEDIMENTOLOGICAL FIELD OBSERVATIONS: STRATAL ORGANIZATION AND DEPOSITIONAL ENVIRONMENTS}

\section{LITHOSTRATIGRAPHY AND FACIES ASSOCIATIONS}

Formations were analyzed and classified into various facies associations from field observations. The classification used is mainly based on bedforms, the nature of the contacts of beds, assemblages of sedimentary structures, grain size, sandstone : mudstone ratio, and thickness of sandstone beds. Miall's $(1978,1985)$ lithofacies codes and architectural elements were followed in the present work. The above-mentioned field criteria were also chosen for a regional comparison of the evolution of the Neogene fluvial system, as carried out by Nakayama and Ulak (1999). Altogether, seven facies associations (KFA1-KFA7) have been distinguished (Table 1). The upper and/or lower limits of the facies KFA1-KFA7 are all positioned along the section with reference to the 476 samples collected by Gautam and Fujiwara (2000) (Fig. 2). In the present 
paper, the term 'sandstone' is used; however, most of the observed sandstones have a variable silty-clayey matrix and some of them should be called greywacke.

KFA1 facies association

The KFA1 facies association (Table 1; Fig. 2) is characterized by a predominance of thick-bedded mudstone $(1-3 \mathrm{~m})$ interbedded with fine-grained gray calcareous sandstone $(0.5-2.0 \mathrm{~m})$. Typically, $1.5-5.0 \mathrm{~m}$ of fining upward sequences from sandstone to mudstone beds are found in this facies. The basal contact (with the underlying sequence) is marked by an erosion surface and sandstone gradually passes upward into mudstone. Calcareous nodules occur on the 10-20-cm-thick upper surfaces of the sandstone beds and occasionally in the bioturbated highly pigmented mudstones above. Rootlets may be found, indicating the development of vegetation at the top of the fining upward sequence. Laterally accreted architectures may be found in the thicker sandstone beds. Some sequences with reddish thicker beds of medium-coarse sandstone and minor mudstone beds are found in the KFA1 series. Their basal surface is more erosive than fine-grained calcareous sandstone and the base of each sandstone bed contains many intraformational mud clasts. For the overall KFA1 facies association, the sandstone to mudstone ratio, abundance of laterally accreted sandstone and intraformational clasts increase stratigraphically upward.

KFA2 facies association

The KFA2 facies association (Table 1; Fig. 2) is characterized by alternating medium-coarsegrained sandstone beds and a set of several finegrained muddy sandstone beds. The frequency of mudstone layers is reduced against the KFA1 association. The coarser sandstone beds are 2-10 m thick. They are frequently ribbon-lensoid in shape with lateral accretionary architectures. Their basal surface, which is slightly erosive, is overlain by many intraformational mud clasts, of centimeter to decimeter scale. The top parts of these sandstone beds consist of finer bioturbated sandstone. The finer-grained sandstone beds have a sheet-like geometry and tabular, sometimes slightly undulated, basal surfaces. They show centimeter-scale laminations and locally grade into mudstone beds, the top of which is truncated by the overlying fine-grained sandstones. Therefore, the fine-grained muddy sandstones could be amalgamated sandstones. The thickness of these finegrained sandstone beds and intercalated mud layers varies, from 20 to $100 \mathrm{~cm}$ and from 10 to $20 \mathrm{~cm}$, respectively.

\section{KFA3 facies association}

The KFA3 facies association (Table 1; Fig. 2) consists of an alternation of thick medium-coarsegrained gray sandstone beds and thinner sequences of fine-grained muddy sandstone and mudstone beds. The basal surface of coarser grained sandstone beds is erosional. Many centimeter-to decimeter-sized intraformational mud clasts and rounded indurated gravels derived from older Siwalik formations are commonly found.Horizontal stratification and mostly trough crossstratification are developed in the mediumcoarsegrained sandstone beds, which form accretionary architectures. The coarser sandstone beds are 5-8 m thick. The muddy sandstone beds are locally ripple laminated and frequently overlie bioturbated green to gray mudstone beds. Both muddy sandstone and mudstone beds have a thickness of approximately $2-3 \mathrm{~m}$. Some thin dark-gray mudstone beds occur stratigraphically upward.

KFA4 facies association

The KFA4 facies association is characterized by light-gray, thick and coarse- to very coarsegrained horizontal and trough cross-stratified sandstone beds (Table 1; Fig. 2). Pebbly sandstones and gray-brown to gray-green mudstones are interbedded. In most cases, the coarse sandstone beds approximately $10 \mathrm{~m}$ thick have a nonerosional planar basal surface, whereas a few thinner coarse sandstone beds show several decimeter-scale deep erosional scours. At their bottom, the coarse sandstone beds contain layers of intraformational mud clasts, reaching up to $50 \mathrm{~cm}$ in thickness. Pluri-decimetric lenses of laminated clays and paleosols may also be found in these layers. The grain size of the thick sandstone beds decreases stratigraphically upward and the sandstone beds show ripples at their top. The thickness of interbedded pebbly sandstone ranges between 30 and $100 \mathrm{~cm}$. The majority of the subrounded to rounded gravels and cobbles are of quartzite with a length and breadth of up to 5 and $15 \mathrm{~cm}$, respectively, whereas the Siwalik cobbles show a length of up to $20 \mathrm{~cm}$. Mudstone beds, when present, are $50 \mathrm{~cm}$ to $3 \mathrm{~m}$ thick. Rootlets have not been found in mudstones. Near the top of the KFA4 facies association, several sandy beds containing inclined, sometimes flat gravels and cobbles occur. These beds are approximately $60-100 \mathrm{~cm}$ thick and truncate the underlying light-gray sandstone. They occur every $2-10 \mathrm{~m}$ and no mudstone is observed in between. Gravels and cobbles consist mainly of quartzite, subangular sandstone and mudstone, the latter showing a 'tile-type' geometry with a common orientation (Fig. 2). No grading is observed in these beds and the matrix is composed predominantly of very coarse sand. 


\section{KFA5 facies association}

The KFA5 facies association is characterized by light-gray and thick, coarse- to very coarsegrained sandstone beds, pebbly sandstones and gray mudstones (Table 1; Fig. 2). The coarse- to very coarse-grained sandstones are commonly planar and cross-stratified. Trough stratified gravel beds are also observed. Clasts consist essentially of 3-10-cm rounded quartzite and sandstones pebbles. The basal surface of coarse- to very coarsegrained sandstone beds is mostly nonerosive and almost flat, whereas it is erosive in the case of the pebbly sandstones. Mudstone beds are rare and their thickness varies from 30 to $100 \mathrm{~cm}$.KFA6 facies association The KFA6 facies association consists of coarse buff sandstone beds interlayered with gray to green mudstones (Table 1; Fig. 2). The proportion of buff sandstones relative to mudstones increases stratigraphically upward. The basal surface of the very coarse-grained sandstones is erosive, and exotic gravels, mainly of quartzite, up to $10 \mathrm{~cm}$ in diameter occur at the base of these beds. Sandstones of the KFA6 facies association are homogenous, poorly indurated and contain fewer white mica in comparison with the sandstones of the former facies. Cross-stratifications and convolute features may be observed. The thickness of the coarsegrained sandstones ranges from a few decimetres to approximately $3 \mathrm{~m}$. Mudstone beds have sizes varying between several decimeters to a few meters and show bioturbation. A few conglomerate beds, approximately $1 \mathrm{~m}$ thick, occur stratigraphically upward.

KFA7 facies association

The KFA7 facies association consists of moderately sorted pebble- and cobble-sized massive clastsupported conglomerates (up to $20 \mathrm{~m}$ thick). Erosional surfaces and cross-stratifications are observed locally. Subordinate lenses of sandstones, 1-5 m thick, may occur (Table 1; Fig. 2). The conglomerate clasts are rounded to subrounded in shape and of Himalayan crystalline and Siwalik origin. The yellowish matrix is coarse and micaceous.

\section{DEPOSITIONAL ENVIRONMENTS}

The KFA1-KFA5 facies associations are very similar to the FA1-FA5 facies associations defined by Nakayama and Ulak (1999) and Ulak and Nakayama (2001), who studied the Surai Khola, Tinau Khola and Bakiya Khola sections (Siwaliks in west and central Nepal). In addition, KFA7 is similar to the FA6 in the Tinau Khola and FA7 in the Surai Khola and Bakiya Khola. However, the KFA6 facies association that was observed along the Karnali section in the present study has only been recognized along the Surai section.

The facies associations FA1-FA6 identified by Ulak and Nakayama (2001) correspond, respectively, to a meandering system, a flood-flowdominated meandering system, a flood-flow-dominated shallow sandy meandering system, a deep sandy braided system, a shallow sandy braided system and a gravely braided system. Using the analogy between the facies observed in the present study and those observed in Ulak and Nakayama's (2001) study, as well as further detailed analysis, the following evolution for the Karnali River system is proposed (Fig. 2): 1. From 15.8 to 13.1 Ma (KFA1), the sedimentation resulted from a fine-grained meandering river system. Frequent paleosols developed, which attest to long-term exposure of the flood plain. 2. From 13.1 to $12.6 \mathrm{Ma}$ (KFA2), the meandering system remained quite stable, with the occurrence of flood flows as suggested by the amalgamated fine-grained sandstone. 3. From 12.6 to $9.5 \mathrm{Ma}$ (KFA3), deposits led to a meandering system with increasing discharge. 4. From 9.5 to 6.4 Ma (KFA4), sedimentation resulted from a sandy braided system. Starting from approximately 7.5 Ma, several conglomeratic beds truncating the underlying deposits and without any sorting occur. They could correspond to erosional and immediately succeeding depositional episodes such as flooding events. This set of flooding events indicates an irregular stream discharge. 5. Between 6.4 and 5.5 Ma (KFA5), the sandy braided river system persisted with discontinuous sedimentation and frequent and episodic high energy discharge events. 6. From 5.5 to 4.0-3.7 Ma (KFA6), the difference in sandstone composition and increase of the relative proportion of the overbank deposits suggest an intermediate period when the drainage system was reorganized and changed to a river fed by piedmont streams, providing a more proximal supply. 7. From approximately 3.9-3.7 Ma (KFA7), a gravelly braided river system developed.

\section{EVOLUTION OF STREAM ENERGY}

The form of the basal surface of sandstone beds results from a competition between discharge and sediment load. Although analyzed in 2-D, some of the strongly erosive sandstone bases observed along the Karnali River section could underline fluvial channels (Fig. 2). From the consistent increase in several 
variables, such as the depth of the channels, the amount of intraclasts in the basal channels, bedload and the grain size, an increase of energy from KFA1 to KFA7 is noticeable in the fluvial system. For KFA1 and KFA2, the main sandy channels are slightly erosive, suggesting a gentle fluvial system with low discharge. The erosive basal surface of sandstone beds in KFA3 indicates the increasing energy of the stream. In contrast, the major deep channels occurring with the KFA4 facies association display nonerosional basal surfaces, suggesting an increase in sediment load relative to discharge capacity. Erosive pebbly sandstones, several decimetres thick, are recognized as large-magnitude flood interbeds. Their occurrence increases upsection within KFA4. Together with an increasing proportion of intraformational mudclasts, the pebbly sandstones suggest frequent increases in the magnitudes of hydrodynamic parameters, which could be linked to an increase in seasonal discharge. Both KFA5 and KFA7 show a regular increase in sediment load, with low erosive sandstone beds and massive gravels. KFA6 is associated with a higher proportion of mudstone, especially at the beginning of the deposition. The basal erosive channels indicate a decrease in sediment load relative to discharge. Channels and sand bodies have a much smaller size. These conditions could correspond to a lateral shift of the stream in an interfluvial zone and/or a decrease of sediment supply linked to a modification of the catchment basin, as suggested by Gupta (1997) and Kumar et al. (1999).

\section{MINERALOGY AND GEOCHEMISTRY}

\section{CLAY MINERAL ASSEMBLAGES \\ Analytical methods}

Clay mineral assemblages have been extracted from both coarse-grained and muddy layers. Analysis of the clay mineralogy was performed by Xray diffraction at the University of Grenoble, using a Philips PW 1120/90 diffractometer. Samples were gently crushed to obtain grains of approximately $2 \mathrm{~mm}$ in diameter and were then decarbonated in $0.2 \mathrm{~mol} / \mathrm{L} \mathrm{HCl}$. The excess acid was removed by repeated centrifuging followed by homogenization. The $<2-\int \mathrm{m}$ fractions were collected by decantation after settling, and oriented aggregates were made on glass slides. The X-ray diffractograms were made using an untreated sample, a glycolated sample and a sample heated for $2 \mathrm{~h}$ at $490^{\circ} \mathrm{C}$. The method of semiquantitative estimation is based on the peak heights of clay mineral peak, assuming that these weighted amounts added up to 100\% (Capet et al. 1990). Final data are given in percent, the relative error being approximately $\pm 5 \%$ (Holtzappel 1985). The values of illite crystallinity (KI) correspond to the full width at half maximum of the $10 \AA$ peak, and this measurement (in $\otimes^{\circ} 2 \cup$ ) is made on the X-ray diffractogram obtained from the glycolated sample (Kübler \& Goy-Eggenberger 2001). The KI measurement is a statistical means to determine the low metamorphic grade in sedimentary terrains. With increasing burial and very low-grade metamorphism, smectites, illite-smectite mixed-layers and illites (re-)crystallize and progressively transform into illites and finally into muscovite. These transformations, very complex in detail, lead to a progressive decrease in the width of the $10 \AA$ peak as measured on an X-ray diffractogram. Therefore, low KI values correspond to well-crystallized minerals, whereas high KI values indicate poorly crystallized minerals. The KI measurements allow us to establish three subdivisions within a very low-grade metamorphism: diagenesis, anchizone and epizone. With the Philips PW 1120/90 diffractometer $(\mathrm{Cu}-\mathrm{K} /$ radiation) used in Grenoble, the diagenesis-anchizone boundary is defined at 0.42 $\left(\otimes^{\circ} 2 \cup, \mathrm{Cu}-\supseteq()\right.$ and the anchizone-epizone limit is defined at $0.25\left(\otimes^{\circ} 2 \cup, \mathrm{Cu}-\supseteq()\right.$.

Results

The $<2-\int \mathrm{m}$ fraction of the Siwalik Formations along the Karnali River shows a clayey series with illite, chlorite, kaolinite, smectites and mixed layers (illite-smectite/chlorite-smectite). From the mineralogical variations of the clay fraction, three main periods can be distinguished (Fig. 3a): (i) period 1 - sediments older than 9.5 Ma are dominated by illite- and chlorite-rich assemblages (more than $50 \%$ of (Ill + Chl)/@ clays); (ii) period 2 - sediments between 9.5 and 6.5 Ma old show rapid alternations of smectite-/kaolinite- and illite/chlorite-rich banks (KFA4 facies association); and (iii) period 3 - sediments younger than 6.5 Ma are dominated by smectite- and kaolinite-rich assemblages (KFA5-KFA7). The KI values vary from 0.14 to 0.52 $\otimes^{\circ} 2 \cup$ - that is, from well-crystallized minerals, with crystallinity similar to that of the muscovites from the High Himalaya, to poorly crystallized minerals (Fig. 3b). From the base of the section (approximately $5300 \mathrm{~m}$ ) to $3200 \mathrm{~m}$ (ca $9.5 \mathrm{Ma}$ ), KI values vary between 0.26 and $0.52 \otimes^{\circ} 2 \cup$, indicating conditions of anchizone or diagenesis. From $3200 \mathrm{~m}$ to approximately $2100 \mathrm{~m}$ (ca $6.5 \mathrm{Ma}$ ), KI values range between 0.14 and $0.46 \otimes^{\circ} 2 \cup$, suggesting conditions varying from epizone to diagenesis domains. Finally, from approximately $2100 \mathrm{~m}$ to the 
upper part of the section, illite crystallinity improves, with KI values ranging from 0.30 to $0.14 \otimes^{\circ} 2 \cup$, suggesting a domain of epizone. The observed crystallinity deterioration from a depth of approximately $2100 \mathrm{~m}$ (samples older than $6.5 \mathrm{Ma}$ ) corresponds to an increasing proportion of illite-smectite-mixed layers (Fig. 4), which are linked to the illitization of smectites as a response to increasing temperature with burying (Lanson et al. 1995). Such a transformation begins at approximately $70-95^{\circ} \mathrm{C}$ (Dunoyer de Segonzac 1970), a domain of temperature that was reached at a depth of approximately 1800-2200 m in the Siwalik Foreland Basin, as determined by Robert (2005) from apatite fission tracks. However, if this burying effect is taken into account, the three periods of different dominant clay assemblages defined above are still discernible. In the case of samples that were buried to less than $2100 \mathrm{~m}$ (younger than $6.5 \mathrm{Ma}$ ), the proportion of illite-smectite-mixed layers is independent of KI values that fall in the domain of epizone (Fig. 4). Finally, the above-mentioned KI characteristics suggest that the clay fraction of the Siwalik Formations mainly contains 'inherited illites' that were affected by epizone-type metamorphism. From a depth of approximately $2100 \mathrm{~m}$, illite particles consist of a mixture of inherited illites and illites derived from smectite-illite transformation.

\section{EVOLUTION OF THE NEODYMIUM ISOTOPE COMPOSITION Analytical methods}

Neodymium (Nd) isotope compositions, determined on whole rocks after classical acid digestion and liquid chromatographic separation, were measured on a Finnigan-MAT 262 in static mode (Galy et al. 1996; and references therein). $\mathrm{Nd}$ isotope ratios were normalized to ${ }_{146} \mathrm{Nd} /{ }_{144} \mathrm{Nd}=0.7219$; the ${ }_{143} \mathrm{Nd} / 144 \mathrm{Nd}$ ratio of the La Jolla standard averaged to $0.511854 \pm 0.000016(1\}, n=47)$. For samples or standards, the typical 2 $\lceil$ precision for a single run was 0.000008 . Blank contributions are negligible for the amount of analyzed elements.

Results

Neodymium isotopes are useful for distinguishing rocks of the Lesser Himalaya from the Higher Himalaya (France-Lanord et al. 1993; Galy et al. 1996; Robinson et al. 2001) in central and western Nepal. They allow us to determine the main source area of the detritus deposited in the Siwalik Foreland Basin (Huyghe et al. 2001). 1. The $\sum_{\mathrm{Nd}}(0)$ values of the sediments of the Karnali section range from $\square 14.6$ to $\square 17.9 \%$ (Fig. 5; Table 2). They are close to those of the modern Higher Himalaya and suggest that the detrital input of the Siwalik sediments was predominantly derived from the erosion of formations analogous to the modern Higher Himalaya (France-Lanord et al. 1993; Ahmad et al. 2000), although a variable but minor proportion of Lesser Himalayan material was present. Two main points can be outlined: from the Middle Siwaliks (inclusive) to the end of the deposition of Siwalik sediments, $\sum_{\mathrm{Nd}}(0)$ values decrease, implying an increase in the proportion of the Lesser Himalayan material with time. Similar results have been obtained in the

Surai Khola section (Huyghe et al. 2001; Robinson et al. 2001). Assuming an average $\sum_{\mathrm{Nd}}(0)$ composition of $\square 15.2 \%$ for the Higher Himalaya and $\square 22.7 \%$ for the Lesser Himalaya (Robinson et al. 2001) and using a mixing equation (Allegre 2005), the contribution of the Lesser Himalaya increased from $<10 \%$ for the Lower Siwalik samples to approximately 30-35\% for the Middle and Upper Siwalik samples. 2. A high proportion (approximately 30\%) of Lesser Himalayan input started abruptly at ca $10 \mathrm{Ma}$ (at the end of facies KFA3) in the Karnali section, indicating local exhumation of Lesser Himalayan rocks in the catchment basin. The exhumation of the Lesser Himalayan rocks has been controlled by the thin-skinned tectonics of the Lesser Himalayan thrust system, and would have begun at 12-10 Ma, taking into account the delay for denudation (Huyghe et al. 2001; and references therein).

\section{DISCUSSION}

COMPARISON OF THE SEDIMENTARY RECORDS IN VARIOUS SECTIONS OF THE NEPALESE SIWALIKS AND THE BENGAL FAN

Regional evolution of the Neogene fluvial system -Bakiya, Tinau, Surai and Karnali sections

Comparison of the facies analysis performed along the Karnali River section with similar studies by Nakayama and Ulak (1999) and Ulak and Nakayama (2001) along the Surai, Tinau and Bakiya sections (Fig. 1a), shows similar changes in the fluvial system during the Upper Miocene in the Siwalik Basin from central to western Nepal (Fig. 6). Magnetostratigraphic ages are based on the studies of Appel et al. (1991), Gautam and Appel (1994) and Harrison et al. (1993), respectively, all of them updated to the geomagnetic polarity 
timescale of Cande and Kent (1995) by Gautam and Rösler (1999). Fluvial changes are diachronous over a distance of approximately $500 \mathrm{~km}$, with age gap varying from 1.1 to $4.5 \mathrm{Ma}$, which seems common for fluvial system dynamics in the Himalayan Foreland Basin (Brozovic \& Burbank 2000). The fluvial changes are in general older along the Karnali River section (western Nepal) than along the other sections; this age difference could probably be a result of the larger size of the Karnali Catchment Basin. Owing to the large size, the Karnali depobasin was probably more sensitive to variations in discharge, sediment supply (larger surfaces affected by erosion and a larger variety of rocks) and tectonics from both the High Himalaya and Lesser Himalaya domains. The minimum age gap occurs for the change from sandy to shallow sandy braided system (KFA4-KFA5), which occurs between 6.6 Ma (along the Bakiya section) and 5.5 Ma (along the Tinau section). Keeping in mind the uncertainties of magnetostratigraphy, the 1.1-Ma age gap is maybe not meaningful and the change from sandy to shallow sandy braided system could be considered synchronous over the Siwalik Basin compared with the other changes in fluvial style.

Regional evolution of the Nd isotope composition and clay mineralogy - the Bengal Fan

The observed trends of the $\sum_{\mathrm{Nd}}(0)$ in the Siwaliks are consistent with the slight decrease of $\sum_{\mathrm{Nd}}(0)$ compositions of Bengal Fan sediments (since $8 \mathrm{Ma}$ ), where a comparable range of compositions was detected (France-Lanord et al. 1993; Galy et al. 1996). A Lesser Himalayan contribution is also inferred from radiogenic Os isotopic sediment in both Bengal Fan and Siwalik constituents (Pierson-Wickmann et al. 2000). The unique source of such radiogenic Os in Himalaya is the black shale of the Upper Lesser Himalaya (Pierson-Wickmann et al. 2000), implying that the Lesser Himalaya was locally exposed to erosion since at least ca 12 Ma. Results similar to those of the Karnali section have been obtained from the clay mineral assemblages of Ocean Drilling Project Leg 116 and Deep Sea Drilling Project Leg 22 (Bouquillon et al. 1990; Derry \& France-Lanord 1997; Galy 2003), where the occurrences of smectite and kaolinite have been linked to variations in environmental conditions at approximately 7 Ma.

\section{ORIGIN OF OBSERVED MAIN CHANGES}

The sedimentological data described above show that two kinds of changes in the fluvial system are contemporaneous with major changes in the sediment characteristics within the Siwalik Group. First, a major change from a meandering river system to a braided river system occurred at ca 9.5 Ma between KFA3 and KFA4. This change followed an abrupt increase in the Lesser Himalayan detrital input inferred from $\mathrm{Nd}$ isotopes. Second, the change from a deep braided system to a shallow braided system occurred at ca $6.5 \mathrm{Ma}$ between KFA4 and KFA5. It is contemporaneous with an increase of the smectite/kaolinite proportions of the clay mineralogy. A scenario for the tectonic evolution of far western Nepal is proposed from changes in the fluvial style along the Karnali River, clay mineralogy and Nd isotope geochemistry data. The controls of these fluvial changes are then discussed.

A tectonic scenario for the Himalaya of far western Nepal

The gradual decrease of the neodymium isotope values recorded between ca 13.0 and ca 9.5 Ma in the deposits of the Karnali River points to an increased input in the Lesser Himalayan rock material, an event that was attributed to initiation of the Lesser Himalayan tectonics (Huyghe et al. 2001). This hypothesis is supported by the occurrence of zircons of paleoproterozoic age from the Lesser Himalaya, and CambrianOrdovician age derived from the Dadeldhura granite, in the Middle Siwalik sandstones (DeCelles et al. 1998, 2001). In detail, it is proposed here that the propagation of the basal detachment beneath the Lesser Himalaya affected different thrust sheets in the following succession: the hanging wall of the Dadeldhura thrust, the Ramgarh thrust (RT) and the main boundary thrust (MBT) (Fig. 7). Such a scenario of propagation has already been proposed by DeCelles et al. (2001). It also agrees with the significant grain-size increase from Middle Siwalik time to the present day (Huyghe et al. 2001). Here, a more detailed description is provided by taking into account the present results along the Karnali section and by using the following rule based on the example of the recent uplift pattern in central Nepal (Lavé \& Avouac 2001): the motion along the active ramps of the basal detachment induces zones of rapid and localized uplift (Fig. 7) and the proportion of High Himalayan and Lesser Himalayan rocks exposed in these zones of intense erosion controls the supply to the foreland basin and the mélange of source recorded in the Siwalik deposits of the Karnali River section. The main differences between this scenario and the interpretation of DeCelles et al. (2001) are given below: 1. The Dadeldhura sheet did not overly the whole of the Ramgarh sheet. Therefore, the activity of RT led to the erosion of Lesser Himalayan rocks as soon as the foreland basin cover was removed. This tectonic activity controlled the decreasing trend of the neodymium isotope values between ca 13.0 and ca 9.5 Ma in the deposits of the 
Karnali River (Fig. 5); 2. Main boundary thrust initiation occurred at approximately 10-9 Ma and was synchronous with the RT motion. This early and weak activity of the MBT induced erosion of the syn-orogenic sediments located at its hanging wall, the sources of which were mainly derived from the High Himalaya. The continuous RT activity led to the consumption of most of the Lesser Himalayan rocks located at its hanging wall prior to $9.5 \mathrm{Ma}$, and caused erosion of the Dadeldhura sheet after 9.5 Ma. Therefore, the neodymium isotope values recorded at 10.0-9.5 Ma in the foreland basin increased as a result of the activities of both the MBT and RT and also the supply of eroded material mainly from the High Himalayan domain or with affinities close to those of the High Himalaya. The 10-9.5 Ma increase of neodymium isotope values was also synchronous with reactivation of the MCT, evidenced by MacFarlane 1993) in central Nepal. However, the 109-Ma period is marked by the maximum sediment accumulation rate (Gautam \& Fujiwara 2000), a maximum that fits with an increase of the subsidence rate because of the rapid southward migration of the thrust load above the flexed lithosphere rather than a reactivation of the MCT, which would increase the distance between the thrust load and the foreland. Therefore, such a reactivation is not appropriate.

Tectonic control for the change from meandering to braided river system

From the large content of feldspars and biotites in the 'salt and pepper' sandstones of the Middle Siwaliks, Ulak and Nakayama (2001) argued that the onset of the braided river system was caused by rapid uplift of the Higher Himalayan terrain. However, thermochronologic detrital investigations suggest a steadystate erosion (Bernet et al. 2005) or a decrease (Szulc et al. 2004) of the exhumation by that time (10-8 Ma). Therefore our tectonic scenario proposes the following interpretation for the sedimentological evolution pointed out by Ulak and Nakayama (2001): the development of the duplex and the motion along the midcrustal ramp of the RT induced passive uplift and erosion of the High Himalaya and Dadeldhura thrust sheets, whereas the weak activity of the MBT induced erosion of syn-orogenic sediments and of a few Lesser Himalayan rocks; the initiation of the MBT decreased abruptly the distance from the Karnali section to the topographic front and induced, by increasing the river gradient, the transport of coarser sediment load, as revealed by grain-size analysis (Huyghe et al. 2001), and the development of braided river systems, as shown by the KFA3/KFA4 transition of the Karnali section. Following the tectonic sketch proposed above, the evolution from illite/chlorite-rich assemblages prior to $9.5 \mathrm{Ma}$ to a rapid alternation of illite/chlorite and smectite/kaolinite banks could be linked to a change of source material. Recycling of the early foreland basin sediments in the hanging wall of the MBT provided a source of rocks and minerals that consequently suffered two consecutive weathering episodes, then susceptible to produce more clay minerals linked to weathering (Fig. 7c). Some basic intrusives at the base of the Precambrian low-grade metasediments in the Ramgarh thrust sheet could also have been weathered and produced clays with smectites in the Middle Siwaliks. However, the proportion of basic intrusives is minor (Shrestha 1987) and other origins have to be proposed. For example, the formation of smectites from feldspar weathering has already been described in the Siwaliks when fluid circulation is involved (Huyghe et al. 1998). The porosity of the coarse and weakly cemented Middle Siwalik sandstones and the feldspar supply of up to 20\% from 11 to 9 Ma (Tokuoka et al. 1986; Hisatomi 1990; DeCelles et al. 1998) are favorable to such a transformation. In such a case, smectites would form at shallow levels in the foreland basin and would result from an indirect effect of the change of source.

Climatic control for the change from deep sandy to shallow sandy braided river system

The change from deep sandy to shallow sandy braided river system observed at 6.5 Ma along the Karnali River section is characterized by discontinuous sedimentation and frequent and episodic high-energy discharge events. It was preceded by evidence of irregular stream discharge producing large-magnitude flood interbeds. Altogether, these characteristics could be linked to an increase in seasonal discharge. From the tectonic interpretation in the present study (Fig. 7), no major tectonic event occurred between approximately 8 and $5 \mathrm{Ma}$ and the distance between the frontal relief of the Himalaya and the Karnali section remained approximately $50 \mathrm{~km}$. This suggests that the change in fluvial style at $6.5 \mathrm{Ma}$ could be of climatic origin. Moreover, the regional correlation of fluvial styles within the Siwalik Basin (Fig. 6) indicates that it is relatively synchronous over $500 \mathrm{~km}$. Such characteristics also favor a climatic origin. From 7 to $5 \mathrm{Ma}$, an increase of seasonality has been identified in the Siwalik Basin from C and O isotopic analyses of pedogenic carbonates and mollusk shells (Harrison et al. 1993; Quade et al. 1995; Gajurel et al. 2003; Sanyal et al. 2004), and from paleovegetation analysis (Awasthi \& Prasad 1990). This increase of seasonality has been attributed by these authors to a variation in monsoon intensity. From a mineralogical point of view, this change 
in fluvial style occurs during the period of smectite-/kaolinite-dominant clay assemblages. Nd isotopes (Fig. 5) do not indicate any abrupt sourcerock change and no consequent source rock of smectites is noted from 6.5 Ma onward in the Karnali Catchment Basin. As indicated above, the minor surface exposure of basic intrusive is also not enough to explain the long period of smectite abundance in the deposits. As the observed feldspar content in these deposits is lower for the period from 6.5 Ma to the present than during 9.5-6.5 Ma, the formation of higher amounts of smectites as a result of feldspar weathering after $6.5 \mathrm{Ma}$ is not plausible. All these arguments suggest that the abundance of smectites in the clay assemblages from 6.5 Ma onward is linked to strong seasonality that favored the formation of smectites from pedogenetic processes. The pedogenesis occurred in areas characterized by soils preserved from fast physical erosion (i.e. within the zones of weak uplift rate in the Lesser Himalaya and the foreland basin). This supply of smectite-/kaolinite-rich clay assemblages is added to the supply of illite-/chlorite-rich clay assemblages provided by the zones of high uplift, dominated by physical erosion in the High Himalaya.

\section{CONCLUSIONS}

The present multidisciplinary study comprising analysis of facies, clay minerals and $\mathrm{Nd}$ isotopes, conducted along the Karnali River section, permitted us to distinguish several changes in the fluvial system. Six classes of fluvial facies associations among the seven recognized along the Karnali River section have been described previously from three Siwalik sections, from western to central Nepal, stretched over a distance of approximately $500 \mathrm{~km}$. It is notable, however, that the facies boundaries in these sections are diachronous, except in the case of the change from a deep sandy braided river system to a shallow sandy braided system where the time gap is only approximately 1 my. The present study reveals that the difference between fluvial changes induced by tectonics and fluvial changes induced by climatic variations is very small. Difficulty in separating tectonic and climate events is more pronounced in the case of the Himalayas, where tectonics and climate may interact. However, multidisciplinary studies jointly utilizing source markers, weathering indicators and sedimentological parameters give some clues for deciphering climatic and tectonic phenomena. Of the six changes in fluvial systems distinguished along the Karnali River, it is suggested here that at least one of them is linked to tectonic reorganization of the Himalayan belt and another to a climatic change:

1. A tectonic evolution compatible with the major change from a meandering to a braided river system and with the geochemical variations is proposed. The southward propagation of the basal detachment beneath the Lesser Himalaya from ca 13 Ma led to the successive uplift of different thrust sheets, the exhumation and erosion of which controlled the sediment supply to the foreland basin, as shown from the Nd-isotope composition of Siwalik deposits. The activity of the Ramgarh thrust led to erosion of the Lesser Himalayan rocks from ca $12 \mathrm{Ma}$ in the catchment basin of the paleo-Karnali river. The southward propagation of the thrust and fold activities within the outer part of the Lesser Himalaya at approximately 10-9 Ma changed the morphology, the proximity of relief and the surface slope. It was also responsible for the high gradient and sediment load shown by the onset of braided river systems in the paleo-Ganga plain at ca 9.5 Ma.

2. Another significant change from a deep sandy braided to a shallow sandy braided system took place at ca 6.5 Ma. It seems to be of climatic origin as suggested by the discontinuous sedimentation and episodic high-energy discharge and by synchronism of such a change over approximately $500 \mathrm{~km}$. It might be linked to an increase in seasonality also shown by the change from C3 to C4 vegetation and by the abundance of smectites among the clay minerals. Similar results obtained from clay minerals of the distal part of the Bengal Fan attest to the wide impact of this event controlled by the regional evolution climate. The observed indicators ascribed to a climatic change are not totally synchronous along the Karnali River section; the initiation of irregular stream discharge precedes the start of the $6.5 \mathrm{Ma}$ change in the fluvial system by ca $1 \mathrm{Ma}$. This is an indication of a gradual environmental change from approximately 7.5 Ma.

\section{ACKNOWLEDGEMENTS}

This work was supported by the French program 'ECLIPSE' running from 2000 to 2004. We thank P. Gautam, L. P. Paudel and T. Sakai for their constructive reviews and comments on the submitted manuscript. We are also grateful to Professor C. Beck for numerous discussions on fluvial molasses deposits and for improving the analysis of sedimentological field observations.

\section{REFERENCES}


Ahmad T., Harris N., Bickle M., Chapman H., Bunbtury J. \& Prince C. 2000. Isotopic constraints on the structural relationships between the Lesser Himalayan Series and the High Himalayan CrystallineSeries, Garhwal Himalaya. Geological Society of America Bulletin 112, 467-77.

Allegre C. 2005. Geologie Isotopique. Belin, Paris. Allen P. A., Homewood P. \& Williams G. D. 1986. Foreland basins: An introduction. In Allen P. A. \& Homewood P. (eds). Foreland Basins, pp. 3-12. Blackwell, Oxford.

APPEl E., RÖSleR W. \& CoRvinus G. 1991. Magnetostratigraphy of the Miocene-Pleistocene Surai Khola Siwaliks in West Nepal. Geophysical Journal International 105, 191-8.

Auden J. B. 1935. Traverses in the Himalaya. Records of Geological Survey of India 69, 123-67. AwASTHI N. \& PRASAD M. 1990. Siwalik plant fossils from Surai Khola area, Western Nepal. Palaeobotanist

38, 298-318.

BEAUMONT C. 1981. Foreland basins. Geophysical Journal of the Royal Astronomical Society 65, $291-329$.

Bernet M., VAn Der BeeK P., Huyghe P. \& Mugnier J.-L. 2005. Continuous and episodic exhumation of the Central Himalayas from detrital zircon fission-track analysis of Siwalik sediments, Nepal. In Mascle G. \& Lavé J. (eds). 20th HKT Workshop, Abstracts Volume, p. 10. University of Grenoble, Aussois, France.

Bouquillon A., France-Lanord C., Michard A. \& Tiercelin J. J. 1990. Sedimentology and isotopic chemistry of the Bengal Fan sediments: The denudation of the Himalaya. In Cochran J. R., Stow D. A. V., Auroux C. et al. (eds). Proceedings of the Ocean Drilling Program, Scientific Results 116, pp. 43-58. Ocean Drilling Program, College Station, TX.

Brozovic N. \& Burbank D. W. 2000. Dynamic fluvial systems and gravel progradation in the Himalayan foreland. Geological Society of America Bulletin 112, 394-412.

CANDE S. C. \& KENT D. V. 1995. Revised calibration of the geomagnetic polarity timescale for the Late Cretaceous and Cenozoic. Journal of Geophysical Research 97, 13 917-51.

CApet X., Chamley H., Beck C. \& Holtzappel T. 1990. Clay mineralogy of ODP sites 671 and 672, Barbados Ridge Accretionary Complex and Atlantic Abyssal Plain: Palaeoenvironmental and diagenetic implications. In Mascle A., Moore J. C., Taulor, E. et al. (eds). Proceedings of the Ocean Drilling Program, Scientific Results 110, pp. 85-96. Ocean Drilling Program, College Station, TX.

DeCelles P. G., Gehrels G. E., Quade J. et al. 1998. Neogene foreland basin deposits, erosional unroofing, and the kinematic history of the Himalayan foldthrust belt, western Nepal. Geological Society America Bulletin 110, 2-21.

DeCelles P. G., Robinson M. D., QuAde J. et al. 2001. Stratigraphy, structure, and tectonic evolution of the Himalayan fold-thrust belt in western Nepal. Tectonics 20, 487-509.

DelCaillau B. 1992. Les Siwaliks Du Népal Oriental. CNRS Éditions, Paris.

DERRY L. A. \& FrANCE-LANORD C. 1997. Himalayan weathering and erosion fluxes: Climate and tectonics controls. In Ruddiman W. F. (ed.). Tectonic Uplift and Climate Change, pp. 290-312. Plenum, New York.

DunOYER DE SEGONZAC G. 1970. The transformation of clay minerals during diagenesis and low-grade metamorphism: A review. Sedimentology 10, 137-43.

France-Lanord C., Derry L. A. \& Michard A. 1993. Evolution of the Himalaya since Miocene time: Isotopic and sedimentologic evidence from the Bengal Fan. In Treolar P. J. \& Searle M. (eds). Himalayan tectonics. Geological Society of London, Special Publication 74, 603-21.

Gajurel A. P., France-LAnORD C. \& Huyghe P. 2003. Compositions isotopiques (carbone et oxygène) de gatéropodes et bivalves des Siwaliks du Népal: Implications paléo-environnementales sur le système himalayen depuis le Miocène. In Chamley H. \& Trentesaux A. (eds). Colloque Tectoclim, Abstracts Volume, p. 25. Société Géologique de France, Lille, France.

Galy A., France-Lanord C. \& Derry L. A. 1996. The late Oligocene-early Miocene Himalayan constraints deduced from isotopic compositions of early Miocene turbidites in the Bengal Fan. Tectonophysics 260, 109-18.

GALY V. 2003. Etude de la composition isotopique du carbone organique des sédiments du cône du Bengale (Leg 22, Site 218). Masters Thesis, Institut Polytechnique de Lorraine, Nancy, France.

GAUTAM P. \& APPEL E. 1994. Magnetic-polarity stratigraphy of Siwalik Group sediments of Tinau Khola section in west central Nepal, revisited. Geophysical Journal International 117, 223-34.

GAUTAM P. \& FuJIWARA Y. 2000. Magnetic polarity stratigraphy of Siwalik Group of Karnali River section in Western Central Nepal. Geophysical Journal International 142, 812-24.

Gautam P. \& Rösler W. 1999. Depositional chronology and fabric of Siwalik group sediments in Central Nepal from magnetostratigraphy and magnetic anisotropy. Journal of Asian Earth Sciences 17, 659-82.

GUPTA S. 1997. Himalayan drainage patterns and origin of fluvial megafans in the Ganges foreland basin. Geology 25, 11-14.

HARRISON T. M., COPELAND P., HALl S. A. et al. 1993. Isotopic preservation of Himalayan/Tibetan uplift, denudation, and climatic histories in two molasses deposits. Journal of Geology 101, 157-75.

HisAtomi K. 1990. The sandstone petrography of the Churia (Siwalik) Group in the Arung Khola-Binai Khola area, west central Nepal. Bulletin of the Faculty of Education, Wakayama University of Natural Science 39, 5-29. 
Holtzappel T. 1985. Les minéraux argileux, préparation, analyse diffractométrique et détermination. Société Géologique du Nord 12, 1-36.

Huyghe P., Galy A. \& Mugnier J. L. 1998. Microstructures, mineralogy and geochemistry of clay size fraction $(<2$ (m) of thrust zones of western Nepal Siwaliks (Karnali area). Journal of Nepal Geological Society 18, 239-48.

Huyghe P., Galy A., Mugnier J. L. \& Francelanord C. 2001. Propagation of the thrust system and erosion in the Lesser Himalaya: Geochemical and sedimentological evidences. Geology 29, 1007-10.

Kroon D., SteEns T. \& Troelstra S. R. 1991. Onset of monsoonal related upwelling in the western Arabian Sea as revealed by planktonic foraminifers. In Prell W. L. \& Niitsuma N. (eds). Proceedings of the Ocean Drilling Program, Scientific Results 117, pp. 257-63. Ocean Drilling Program, College Station, TX.

KÜBLER B. \& GOY-EgGEnBERGER D. 2001. La cristallinité de l'illite revisitée: Un bilan des connaissances acquises ces trente dernières années. Clay Minerals 36, 143-57.

Kumar R., Ghosh S. K. \& SAngode S. J. 1999. Evolution of a Neogene fluvial system in a Himalaya foreland basin, India. Geological Society of America. Special Paper 328, 239-56.

LANSON B., BeAufort D., Berger G., Petit S. \& LACharpagne J. C. 1995. Evolution de la structure cristallographique des minéraux argileux dans le réservoir gréseux rotliegende des Pays-Bas. Bulletin Centre de Recherche ExplorationProduction Elf Aquitaine 19, 243-65.

LAvÉ J. \& AvouAC J. P. 2001. Fluvial incision and tectonic uplift across the Himalaya of Central Nepal. Journal of Geophysical Research 106, 26 561-93.

MACFARLANE A. M. 1993. Chronology of tectonic events in the crystalline core of the Himalaya, Langtang National Park, central Nepal. Tectonics 12, 1004-25.

MiALl A. D. 1978. Lithofacies types and vertical profile models in braided river deposits. A summary. In Miall A. D. (ed.). Fluvial sedimentology. Canadian Society of Petroleum Geologists, Memoir 5, 597-604.

Miall A. D. 1985. Architectural-element analysis: A new method of facies analysis applied to fluvial deposits. Earth Science Reviews 22, 261-308.

Molnar P. \& England P. 1990. Late Cenozoic uplift of mountain ranges and global climate change: Chicken or egg? Nature 346, 29-34.

Mugnier J. L., Delcaillau B., Huyghe P. \& Leturmy P. 1998. The break-back thrust splay of the Main Dun Thrust (Himalayas of western Nepal): Evidence of an intermediate displacement scale between earthquake slip and finite geometry of thrust systems. Journal of Structural Geology 7, 857-64.

Mugnier J. L., Huyghe P., Jounnne F. \& Leturmy P. 2004. Episodicity rates of thrust sheet motion in the Himalayas (Western Nepal). In McClay K. (ed.). Thrust tectonics and hydrocarbon systems. American Association of Petroleum Geologists Memoir 82, 91-114.

Mugnier J. L., Mascle G. \& Faucher T. 1993. Structure of the Siwaliks of western Nepal: An intracontinental accretionary prism. International Geology Review 35, 1-16.

NAKAYAmA K. \& UlaK P. D. 1999. Evolution of fluvial style in the Siwalik Group in the foothills of the Nepal Himalaya. Sedimentary Geology 125, 205-24.

Pierson-Wickmann A. C., Reisberg L. \& FranceLanord C. 2000. The Os isotopic composition of Himalayan river bedloads and bedrocks: Importance of black shales. Earth and Planetary Science Letters 176, $203-18$.

Powers P. M., LiLlie R. J. \& YeAts R. S. 1998. Structure and shortening of the Kangra and Dehra Dun reentrants, SubHimalaya, India. Geological Society of America. Bulletin 110, 1010-27.

Prell W. L., Murray D. W., Clemens S. C. \& Anderson D. M. 1992. Evolution and variability of the Indian Ocean summer monsoon: Evidence from the western Arabian Sea drilling program. In Duncan R. A. (ed.). Synthesis of Results from the Scientific Drilling of the Indian Ocean, Geophysical Monography Series 70, pp. 447-69. AGU, Washington, DC.

Quade J., Cater J. M. L., OJha T. P., Adam J. \& Harrison T. M. 1995. Late Miocene environmental change in Nepal and the Northern Indian subcontinent: Stable isotopic evidence from paleosols. Geological Society of America. Bulletin 107, 1381-9.

QuAde J., CERling T. E., BARRY J. et al. 1992. A 16-Ma record of paleodiet using carbon and oxygen isotopes in fossil teeth from Pakistan. Chemical Geology 94, 182-92.

Rao R. A., Agarwal R. P., Sharma U. N., Bhalla M. S. \& Nanda A. C. 1988. Magnetic polarity stratigraphy and vertebrate palaeontology of the Upper Siwalik Subgroup of Jammu Hills, India. Journal of the Geological Society of India 31, 361-85.

Ravelo A. C., Andreasen D. H., Lyle M., Lyle A. O. \& Wara W. W. 2004. Regional climate shifts caused by gradual global cooling in the Pliocene epoch. Nature 429, 263-7.

RoBert X. 2005. Analyse thermochronologique des sédiments Siwaliks: Implications pour la séquence de réactivation d'activité des failles et la mécanique du prisme frontal de l’Himalaya. Masters Thesis, Université de Grenoble, Grenoble, France.

Robinson D. M., Decelles P. G., Patchett P. J. \& Garzione C. N. 2001. The kinematic evolution of the Nepalese Himalaya interpreted from Nd isotopes. Earth and Planetary Science Letters 192, 507-21. 
SANyal P., Bhattacharya S. K., Kumar R., Ghosh S. K. \& SANGODE S. J. 2004. Mio-Pliocene monsoonal record from Himalayan foreland basin (Indian Siwalik) and its relation to vegetational change. Palaeogeography, Palaeoclimatology, Palaecology 205, 23-41.

Shrestha S. B. 1987. Geological Map of Far Western Nepal, Scale 1/250 000. Department of Mines and Geology Ministry of Industry, His Majesty’s Government of Nepal, Kathmandu.

SzUlC A., NAJMAN Y., SinClaIR H. et al. 2004. Rapid exhumation of the Greater Himalaya persisted until 10 Ma: New evidence concerning Himalaya evolution during the Neogene from a detrital investigation of the Siwalik group in SW Nepal. American Geophysical Union Fall Meeting, Abstracts Volume. Eos Transactions AGU, San Francisco.

TOKUOKA T., TAKAyAsu K., Yoshida M. \& HisATOMI K. 1986. The Churia (Siwalik) Group of the Arung Khola area, West Central Nepal. Memoirs of the Faculty of Science, Shimane University (Japan) 20, 135-210.

Ulak P. D. \& NAKAyAma K. 2001. Neogene fluvial systems in the Siwalik Group along the Tinau Khola section, West Central Nepal Himalaya. Journal of Nepal Geological Society 25, 111-22.

UpREti B. N. \& LE FORT P. 1999. Lesser Himalayan crystalline nappes of Nepal. Problems of their origin. In Macfarlane A., Quade J. \& Sorkhabi R. (eds). Geological Society of America. Special Paper 328, 225-38.

\section{FIGURES}

Fig. 1 Location map of the study area. (a) Structural sketch of the Himalayas with location of the area considered (western Nepal). Sections cited in the text are, from west to east: Karnali River (KR) section, Surai Khola (SK) section, Tinau Khola (TK) section, Bakiya Khola (BK) section. MBT, main boundary thrust; MCT, main central thrust; MFT, main frontal thrust; RT, Ramgarh thrust. (b) Structural and active-fault map of western Nepal (adapted from Upreti \& Le Fort 1999). Location of Figure 7 is shown.

Fig. 2 Sedimentary facies recognized along the Karnali River section. The ages of the limits of facies KFA1-KFA6 are reported along the simplified lithologic column established by Gautam and Fujiwara (2000). ms., mudstone (clay and siltstone); ms. > ss., mudstone-dominated; pbl.ss., pebbly sandstone; ss., sandstone; ss. >ms., sandstonedominated. Photographs with characteristic features of facies association KFA1-KFA7 are shown on the right side. Their locations are shown by red stars along the lithologic column. (a) Sedimentary facies KFA1-KFA4; (b) sedimentary facies KFA4-KFA7.

Fig. 3 Clay mineralogy of the Siwalik deposits along the Karnali River section. (a) Variation of the ratio (illite + chlorite)/(sum of clays: illite + chlorite+ kaolinite + smectites + illite-smectite mixed layers) vs time. The limits of facies KFA1-KFA7 are reported from their stratigraphic ages. Values for modern samples are plotted along the upper horizontal axis: suspension material from Ganga River during monsoon in Bangladesh (gray triangle); suspension load from Bheri River during monsoon at approximately $700 \mathrm{~m}$ elevation (gray square); modern sands from Karnali River (open circle); rock flour collected at approximately 5050 m elevation (gray star). (b) Variation of illite crystallinity vs depth of the deposits (approximately $5300 \mathrm{~m}$ in stratigraphic thickness). Values for modern samples are shown along the upper horizontal axis by gray stars for rock flour collected at approximately $5050 \mathrm{~m}$ elevation and by gray rectangles for suspended materials from Bheri River down to the Ganga River during monsoon.

Fig. 4 Variation of the illite crystallinity vs the proportion of illite-smectite mixed layers. ( $)$, Samples younger than 6.5 $\mathrm{Ma} ;(\cdot)$, samples older than $6.5 \mathrm{Ma}$.

Fig. $5 \mathrm{Nd}$-isotope composition $\sum_{\mathrm{Nd}}(\%)$ of samples from Siwalik sedimentary rocks of the Karnali River based on data from Huyghe et al. (2001) and new data (the present study). Along the base, the range of $\sum_{\mathrm{Nd}}(0)$ values from the higher Himalayan $(\mathrm{HH})$ zone and Lesser Himalayan (LH) zone from Robinson et al. (2001; and references therein) are shown with the average $\sum_{\mathrm{Nd}}(0)$ value marked with a black bar and the standard deviation of the average marked with gray bars. The limits of facies KFA1-KFA7 have been reported from their stratigraphic ages.

Fig. 6 Regional evolution of the Neogene fluvial system in western and central Nepal from comparison of the Siwalik sedimentary facies identified along the Karnali (circles), Surai (squares), Tinau (triangles) and Bakiya (cross marks) sections. For each section, the following facies are found in order of increasing energy, from left to right: fine-grained meandering system, flood-flow meandering system, flood-flow-dominated meandering system, deep sandy braided system, shallow sandy braided system to gravelly braided system. Interpretation of depositional environments is based on Nakayama and Ulak (1999). The horizontal position of the sections is not to scale. (Ulak \& Nakayama 2001.)

Fig. 7 Incremental balanced restoration of the Himalayan fold-thrust belt in far western Nepal. DT, Dadeldhura thrust; MBT, main boundary thrust; MCT, main central thrust; MFT, main frontal thrust; RT, Ramgarh thrust; 1 , foreland basin; 2, Autochthonous Indian craton; 3, Lesser Himalayan thrust sheet; 4, Ramgarh thrust sheet; 5, duplex of the Lesser Himalaya; 6, Dadeldhura thrust sheet; 7, High Himalaya. Rocks of thrust sheets 2, 3, 4 and 5 have $\sum$ Nd(0) values close to those of the Lesser Himalayan material as given in Figure 5; rocks of thrust sheets 6 and 7 have $\sum_{\mathrm{Nd}}(0)$ values close to those of the High Himalayan material as given in Figure 5 . The final geometry is adapted from the balanced cross-section of DeCelles et al. (2001) using the sequence of thrusting deduced from the present work. The heavy full lines indicate the active thrusts, and the vertical arrows refer to the zones of high uplift at the hanging wall of the ramps. The negative values above the horizontal arrow on the right side correspond to the amount of shortening; the italic values on the left side indicate the distance between the position of the present-day Karnali 
section and the frontal relief of the Himalaya. (a) Geometry at ca $15 \mathrm{Ma}$ - the Dadeldhura thrust sheet overthrusted the Lesser Himalaya prior to $13 \mathrm{Ma}$, tectonics that led to erosion of rocks with High Himalayan affinities. (b) Geometry at ca $11 \mathrm{Ma}$ - the emplacement of the Ramgarh Thrust between 13 and $10 \mathrm{Ma}$ led to the erosion of the Lesser Himalayan rocks ahead of the Dadeldhura thrust sheet. (c) Geometry at ca $8 \mathrm{Ma}$ - the duplexing of the lower part of the Lesser Himalaya after $10 \mathrm{Ma}$ uplifted the Dadeldhura sheet and the High Himalaya, and eroded rocks with $\sum_{\mathrm{Na}}(0)$ values close to those of High Himalayan material. The simultaneous propagation of the detachment thrust to the MBT decreased the distance between the present-day Karnali section and the frontal relief and led to recycling of sediments of the pre-Siwalik Foreland Basin that had $\sum_{N d}(0)$ values close to those of the High Himalayan rocks. (d) Geometry at ca $5 \mathrm{Ma}$ - the main phase of growth of the Upper Lesser Himalayan duplex led to erosion of Lesser Himalayan and High Himalayan rocks. (e) Present-day ( $0 \mathrm{Ma})$ geometry - the uplift above the mid-crustal ramp leads to erosion of the Lesser Himalayan and High Himalayan rocks. 
Table 1 Facies associations recognized in the Siwalik series along the Karnali River section

\begin{tabular}{|c|c|c|c|c|c|}
\hline Magnetostratigraphic sites $\dagger$ & $\begin{array}{l}\text { Age } \\
\text { (Ma) }\end{array}$ & Lithofacies and sedimentary structures $\$$ & $\begin{array}{c}\text { Facies } \\
\text { association }\end{array}$ & $\begin{array}{l}\text { Architectural elements and form of the } \\
\text { basal surface of main sandstone beds } \S\end{array}$ & Interpretation $\mathbb{I}$ \\
\hline & & $\mathrm{Gm}, \mathrm{Gt}-\mathrm{St}-(\mathrm{Fm})$ & KFA7 & $\mathrm{CH}, \mathrm{GB}, \mathrm{DA}$ & Gravelly braided \\
\hline $3980+/-30 \mathrm{~m}$ & $\sim 3.9$ & $\mathrm{PBL}>\mathrm{SS}$ & Upper Siw. & & fluvial system \\
\hline \multirow[t]{2}{*}{$3980+/-30 \mathrm{~m}$} & $\sim 3.9$ & $\mathrm{Gp}, \mathrm{Gt}-\mathrm{Sp}, \mathrm{St}, \mathrm{Cv}-\mathrm{Fm}, \mathrm{Mb}$ & KFA6 & $\mathrm{CH}, \mathrm{GB}, \mathrm{DA}, \mathrm{OF}$ & Anastomosed system \\
\hline & & $\mathrm{SS}>\mathrm{PBL}$ & Middle & Base erosive & \\
\hline G10 & $5.5-5.6$ & & Siw. & & \\
\hline \multirow[t]{2}{*}{$\overline{\text { G10 }}$} & $5.5-5.6$ & $\mathrm{Sp}, \mathrm{St}, \mathrm{Gt}, \mathrm{Se},(\mathrm{Sl})-\mathrm{Sr}-\mathrm{Fm},(\mathrm{P})$ & KFA5 & $\mathrm{CH}, \mathrm{SB}, \mathrm{DA},(\mathrm{LA}), \mathrm{OF}$ & Shallow sandy braided \\
\hline & & “Salt \& pepper" SS & Middle & & fluvial system \\
\hline E20 & 6.4 & & Siw. & & \\
\hline \multirow[t]{2}{*}{ E20 } & 6.4 & $\mathrm{Sp}, \mathrm{Se}, \mathrm{St}-(\mathrm{Sh}), \mathrm{Sr}-\mathrm{Fm}, \mathrm{P}$ & KFA4 & $\mathrm{CH}, \mathrm{LA}, \mathrm{SB}, \mathrm{DA}, \mathrm{OF}$ & Deep sandy braided \\
\hline & & $\mathrm{SS}>\mathrm{SL}+\mathrm{CL}$ & Middle & Base slightly erosive & fluvial system \\
\hline $\mathrm{C} 43$ & 9.5 & “Salt \& pepper" SS & Siw. & & \\
\hline \multirow[t]{2}{*}{$\mathrm{C} 43$} & 9.5 & St, Sp, (Sl), Se, Ss - Fm, Fl, Fsc - P, Fr & KFA3 & $\mathrm{CH}, \mathrm{SB}, \mathrm{DA},(\mathrm{LA})$, amalg, LS, OF & Sandy flood flow- \\
\hline & & $\mathrm{SS}>\mathrm{SL}+\mathrm{CL}$ & Lower & Base erosive & dominated meandering \\
\hline A158 & $12.6-12.7$ & “Salt \& pepper" SS & Siw. & & fluvial system \\
\hline \multirow[t]{2}{*}{ A158 } & $12.6-12.7$ & $\mathrm{Sp}, \mathrm{Sl}, \mathrm{Se}-\mathrm{Fm}, \mathrm{Fl}-(\mathrm{Fr}, \mathrm{P})$ & KFA2 & $\mathrm{CH}, \mathrm{SB}, \mathrm{LA},(\mathrm{amalg}), \mathrm{OF}$ & flood flow-dominated \\
\hline & & $\mathrm{SL}>\mathrm{SS}$ & Lower & Base tabular and slightly erosive & meandering fluvial system \\
\hline A 122 & 13.1 & & Siw. & & \\
\hline \multirow[t]{2}{*}{ A122 } & 13.1 & St, Sp, (Sl) - Fm, Fl, Fsm, (Sh ) - P, Fr & KFA1 & $\mathrm{CH}, \mathrm{SB}, \mathrm{LA}, \mathrm{OF}$ & Fine-grained meandering \\
\hline & & & Lower & Base slightly erosive & fluvial system with low- \\
\hline A1 & 15.8 & $\mathrm{SL}+\mathrm{CL}>\mathrm{SS}$ & Siw. & & discharge and relief \\
\hline
\end{tabular}

$\dagger$ from Gautam and Fujiwara (2000) 
†Fm: mud, silt (massive), Fsc: silt, mud (massive), Gm: massive or crudely bedded gravels, Gt: gravels with trough crossbeds, Gp: gravels with planar crossbeds, $\mathrm{Cv}$ : Convolutes, Sr: sand, very fine to coarse with ripple marks, Sh: sand very fine to very coarse with horizontal laminations, Ss: sand, fine to coarse, with broad, shallow scours, St: sand, medium to very coarse with trough crossbeds, Sp: sand, medium to very coarse with planar crossbeds, Se: erosional scours with intraclasts, Fl: fine laminations and very small ripples within sand, silt and mud, Mb: bioturbated mud, P: carbonate pedogenic features, Fr: rootlets. CL: mudstone, SL: siltstone, SS: sandstone, PBL: conglomerate

$\S \mathrm{CH}$ : channel element, DA: downstream accretion, GB: gravel bar, LA: lateral accretion, LS: laminar sand sheet, OF: overbank fines, SB: sandy bedforms, amalg: amalgamated sandstone

Brackets indicate that lithofacies, sedimentary structures or architectural elements have been observed in the field but are of minor importance.

II from Nakayama and Ulak (1999) 
Table 2 Sr-Nd isotopic compositions of Nepalese Siwaliks samples

\begin{tabular}{|c|c|c|c|c|c|c|c|c|c|}
\hline & "Sample \# & $\begin{array}{l}\text { Age } \\
(\mathrm{Ma})\end{array}$ & $\begin{array}{c}\mathrm{Sr} \\
(\mathrm{ppm})\end{array}$ & 878Sr/86Sr & $\begin{array}{c}\mathrm{Nd} \\
(\mathrm{ppm})\end{array}$ & $\begin{array}{c}\mathrm{Sm} \\
(\mathrm{ppm})\end{array}$ & "143Nd/144Nd & "147Sm/144Nd & $\begin{array}{c}\varepsilon_{\mathrm{Nd}}(0) \\
(\%)\end{array}$ \\
\hline $\bar{\dagger}$ & ka 25 & 1.4 & N.D. & 0.75207 & N.D. & N.D. & 0.511753 & N.D. & -17.3 \\
\hline$\dagger$ & ka 27 & 3.4 & N.D. & 0.73252 & N.D. & N.D. & 0.511803 & N.D. & -16.3 \\
\hline$\dagger$ & ka 29 & 4.1 & N.D. & 0.73034 & N.D. & N.D. & 0.511755 & N.D. & -17.2 \\
\hline$\ddagger$ & Kar 13 & 5.2 & 113.1 & 0.748910 & 33.95 & 2.76 & 0.511829 & 0.118 & -17.6 \\
\hline$\dagger$ & ka 34 & 6.4 & N.D. & N.D. & 17.3 & 3.46 & 0.511831 & 0.127 & -15.8 \\
\hline$\dagger$ & ka 35 & 7.15 & N.D. & N.D. & 37.7 & 7.30 & 0.511846 & 0.123 & -15.5 \\
\hline$\dagger$ & ka 36 & 7.5 & N.D. & N.D. & 33.7 & 6.35 & 0.511840 & 0.120 & -15.6 \\
\hline$\dagger$ & ka 37 & 8.1 & N.D. & N.D. & 29.8 & 5.74 & 0.511808 & 0.122 & -16.2 \\
\hline$\dagger$ & ka 38 & 9.1 & N.D. & N.D. & 31.7 & 6.01 & 0.511830 & 0.120 & -15.8 \\
\hline$\dagger$ & ka 39 & 10 & N.D. & N.D. & 33.4 & 6.43 & 0.511720 & 0.122 & -17.9 \\
\hline$\dagger$ & ka 40 & 10.4 & N.D. & N.D. & 38.1 & 7.36 & 0.511736 & 0.123 & -17.6 \\
\hline$\dagger$ & ka 41 & 11.5 & N.D. & N.D. & 15.0 & 3.38 & 0.511831 & 0.143 & -15.8 \\
\hline$\dagger$ & ka 42 & 12.35 & N.D. & N.D. & N.D. & N.D. & 0.511891 & N.D. & -14.6 \\
\hline$\ddagger$ & Kar 3 & 14.1 & 80.9 & 0.741119 & 33.95 & 6.38 & 0.511829 & 0.114 & -15.8 \\
\hline$\ddagger$ & Kar 1 & 15.9 & 49.1 & 0.753261 & 14.06 & 2.76 & 0.511865 & 0.119 & -15.1 \\
\hline
\end{tabular}



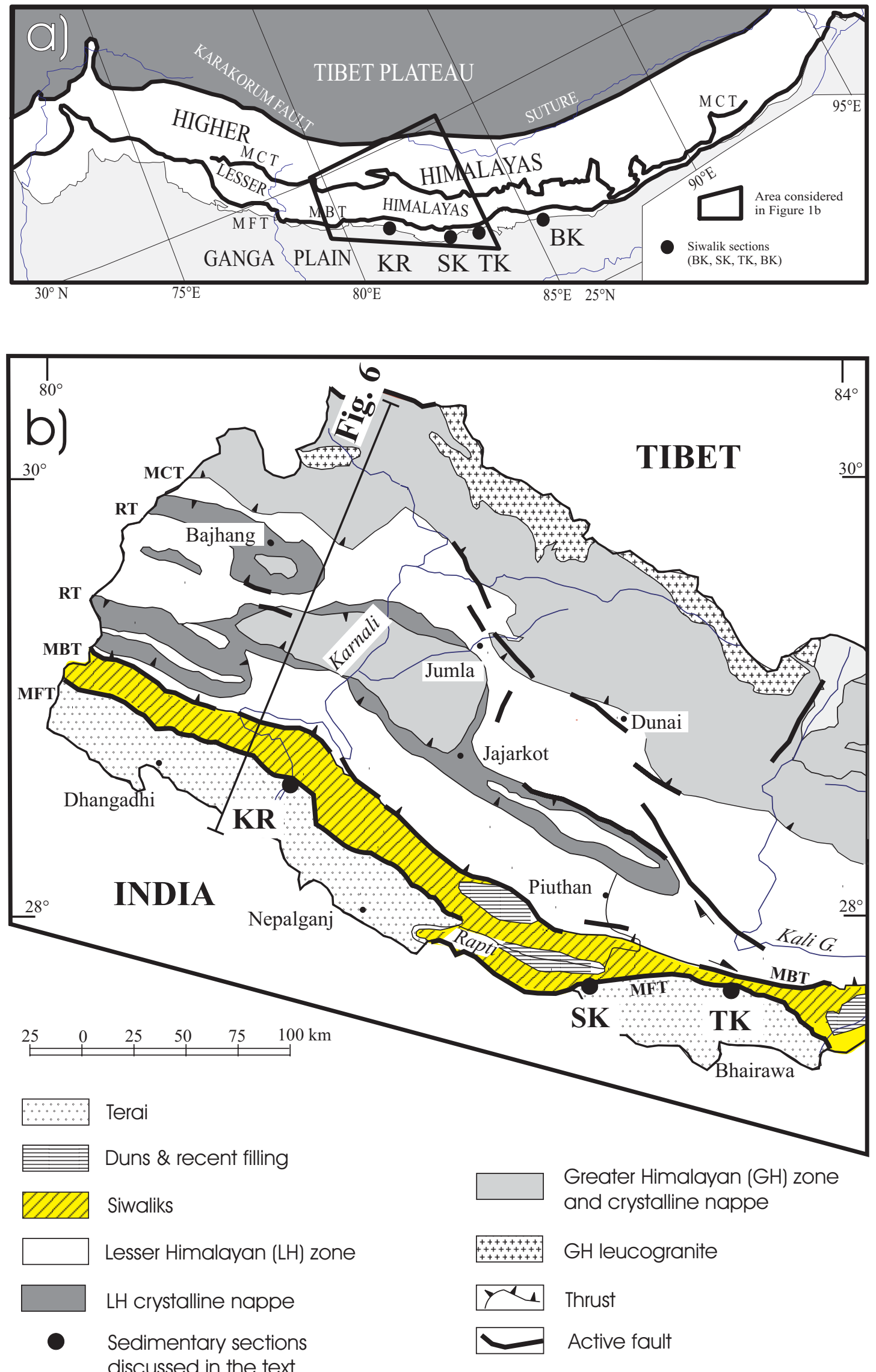

Figure 1 


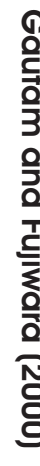

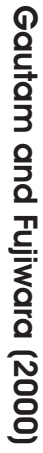

Thickness (m)

$\begin{array}{llllllll}0 & 500 & 1000 & 1500 & 2000 & 2500 & 3000 & (\mathrm{~m})\end{array}$

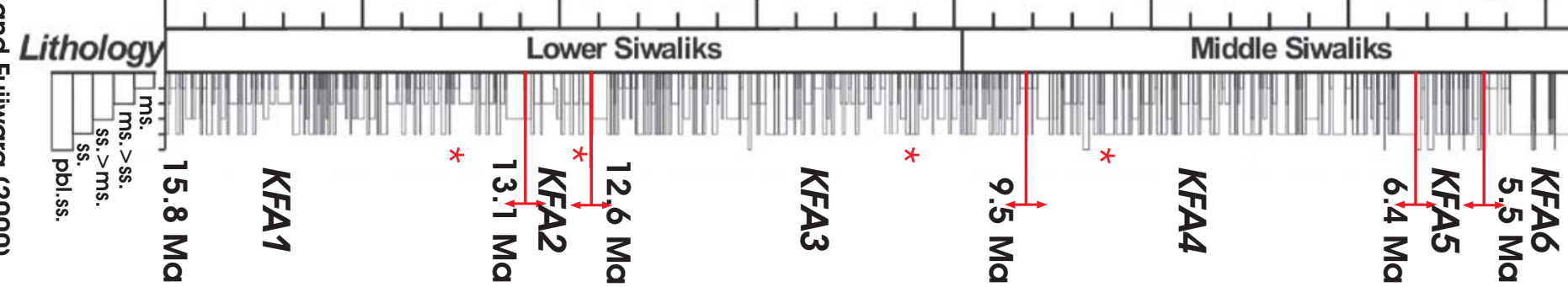
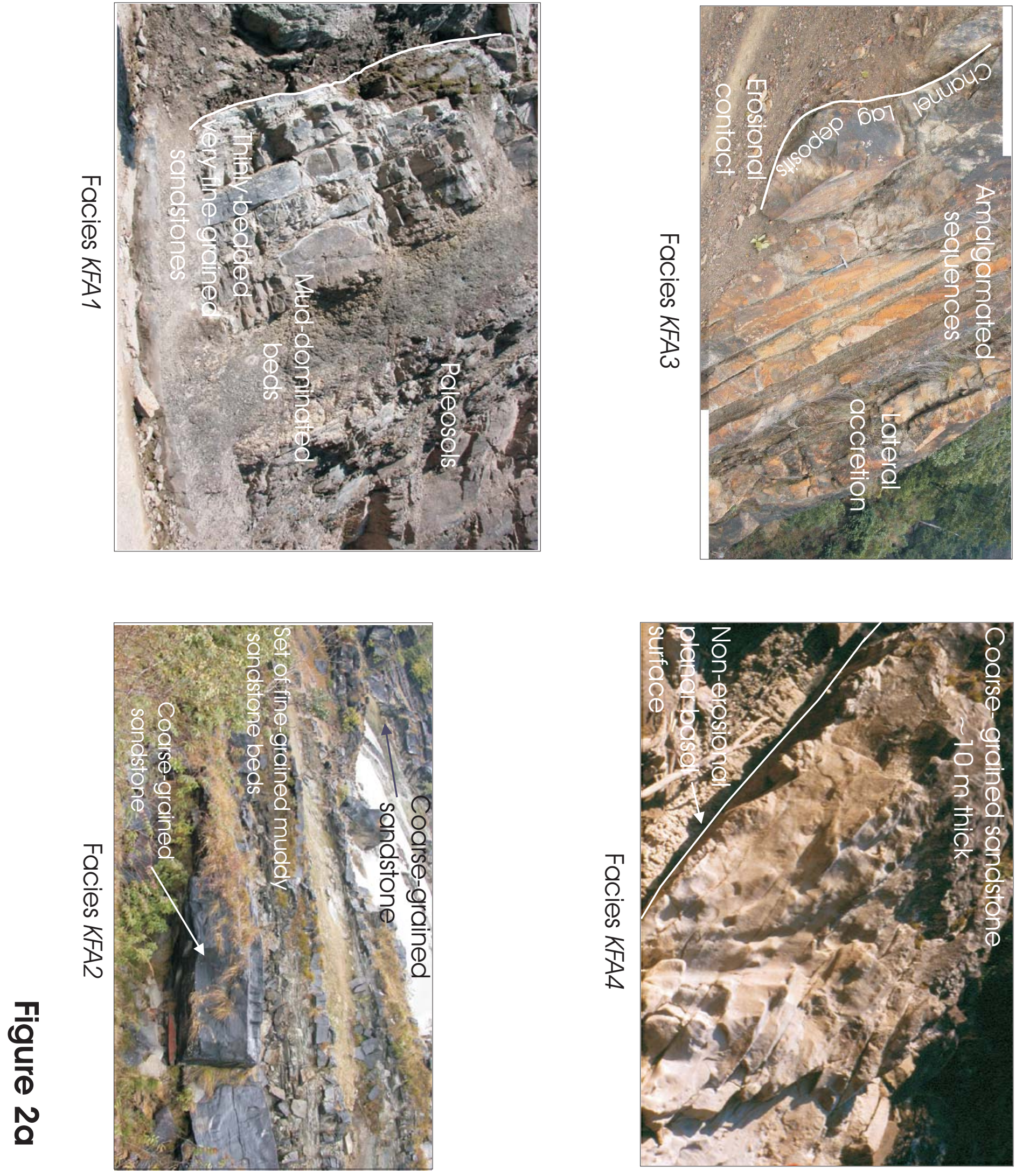


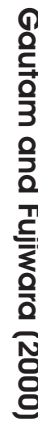
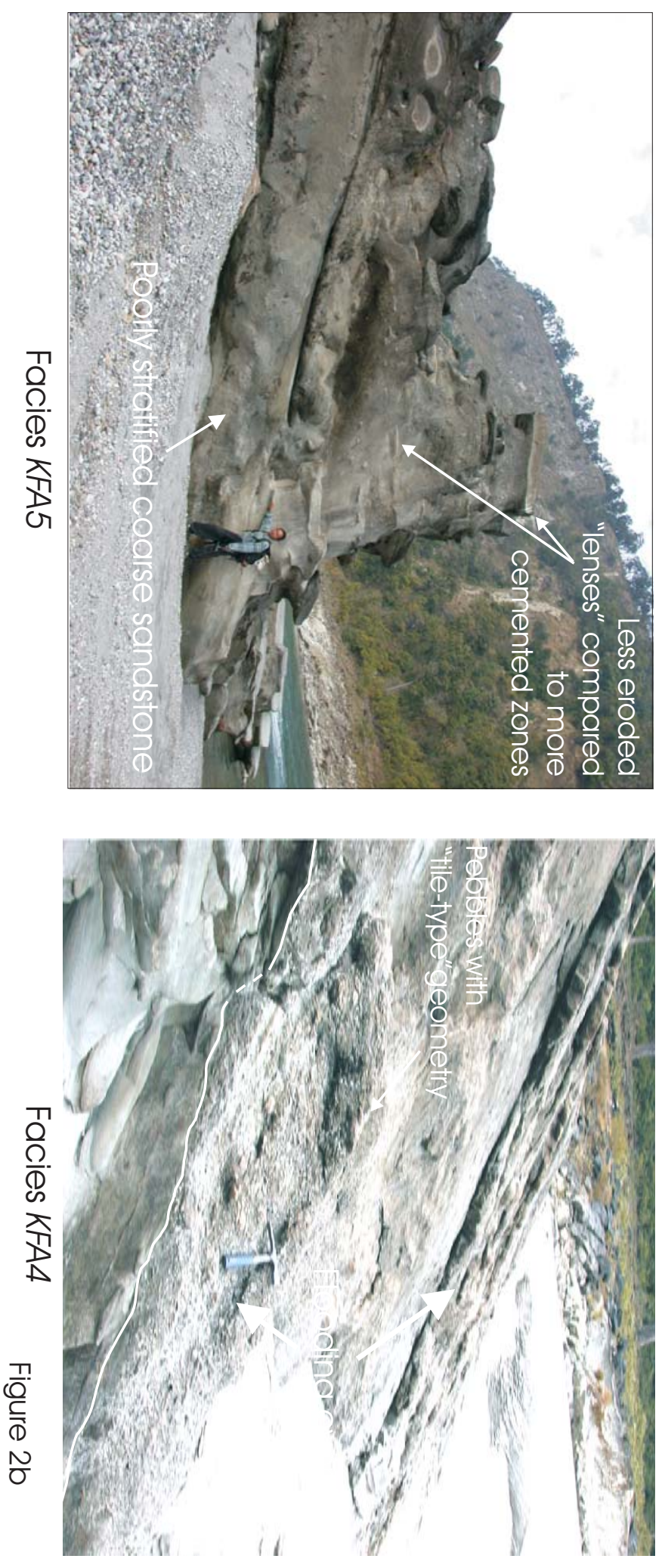

Thickness (m)

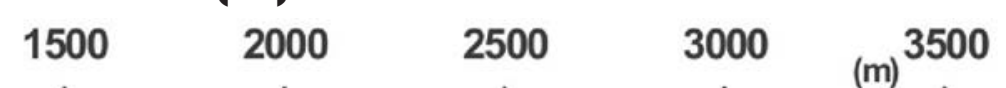
Middle Siwaliks
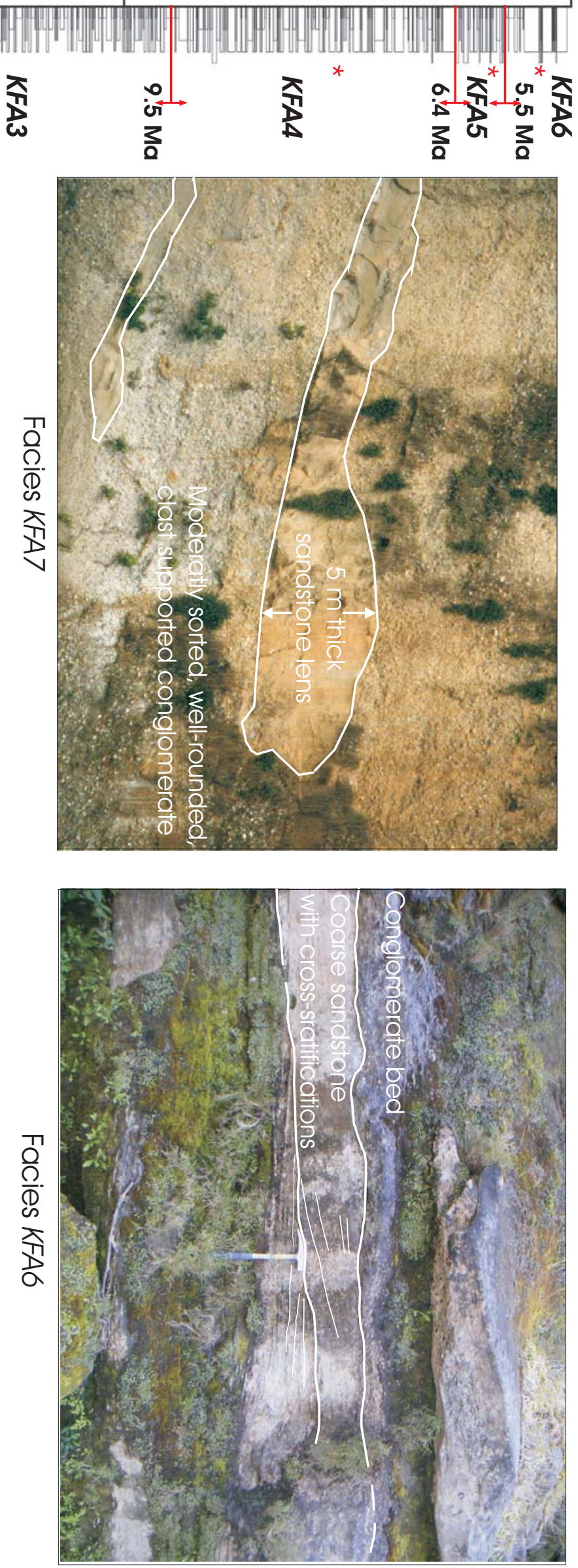


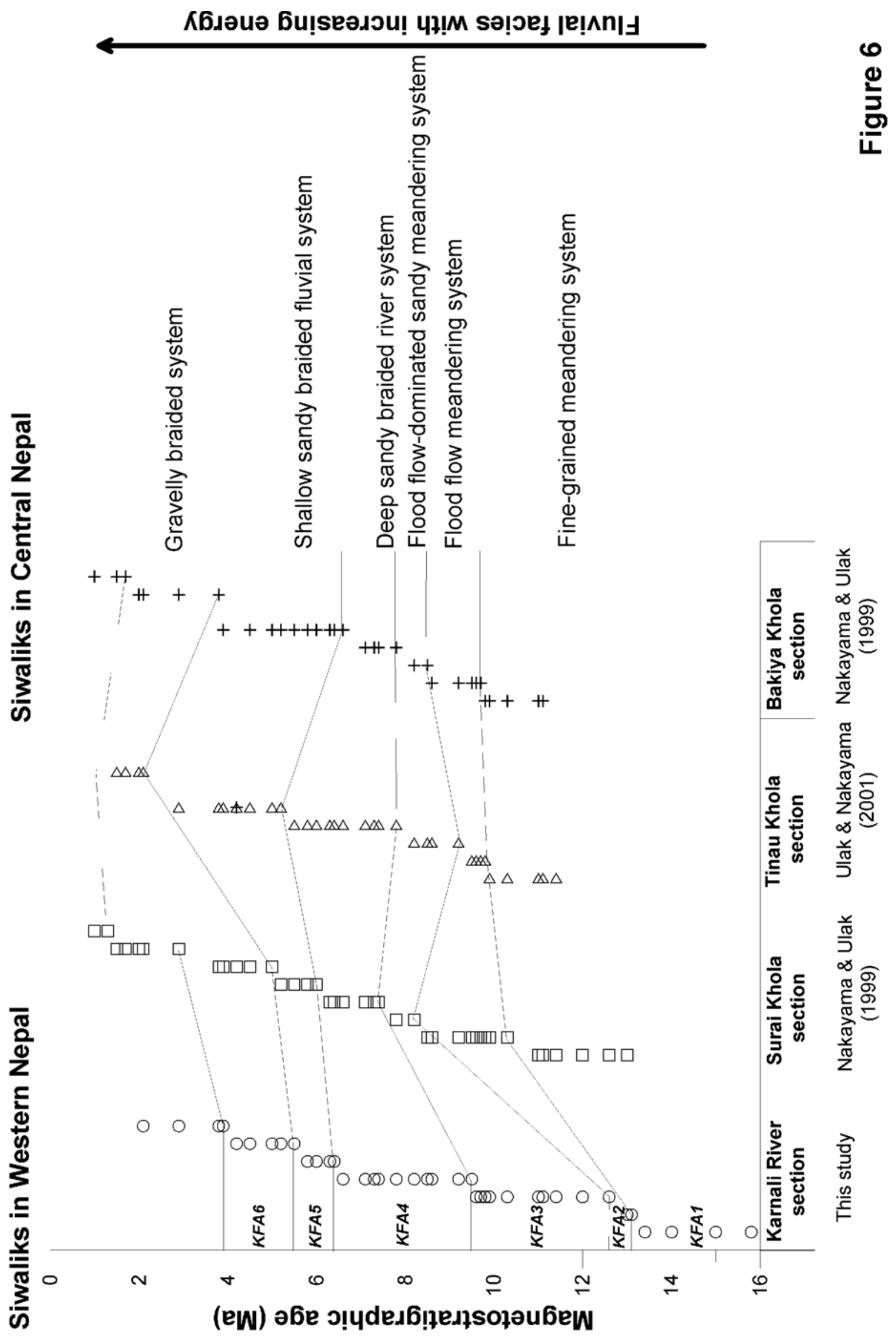




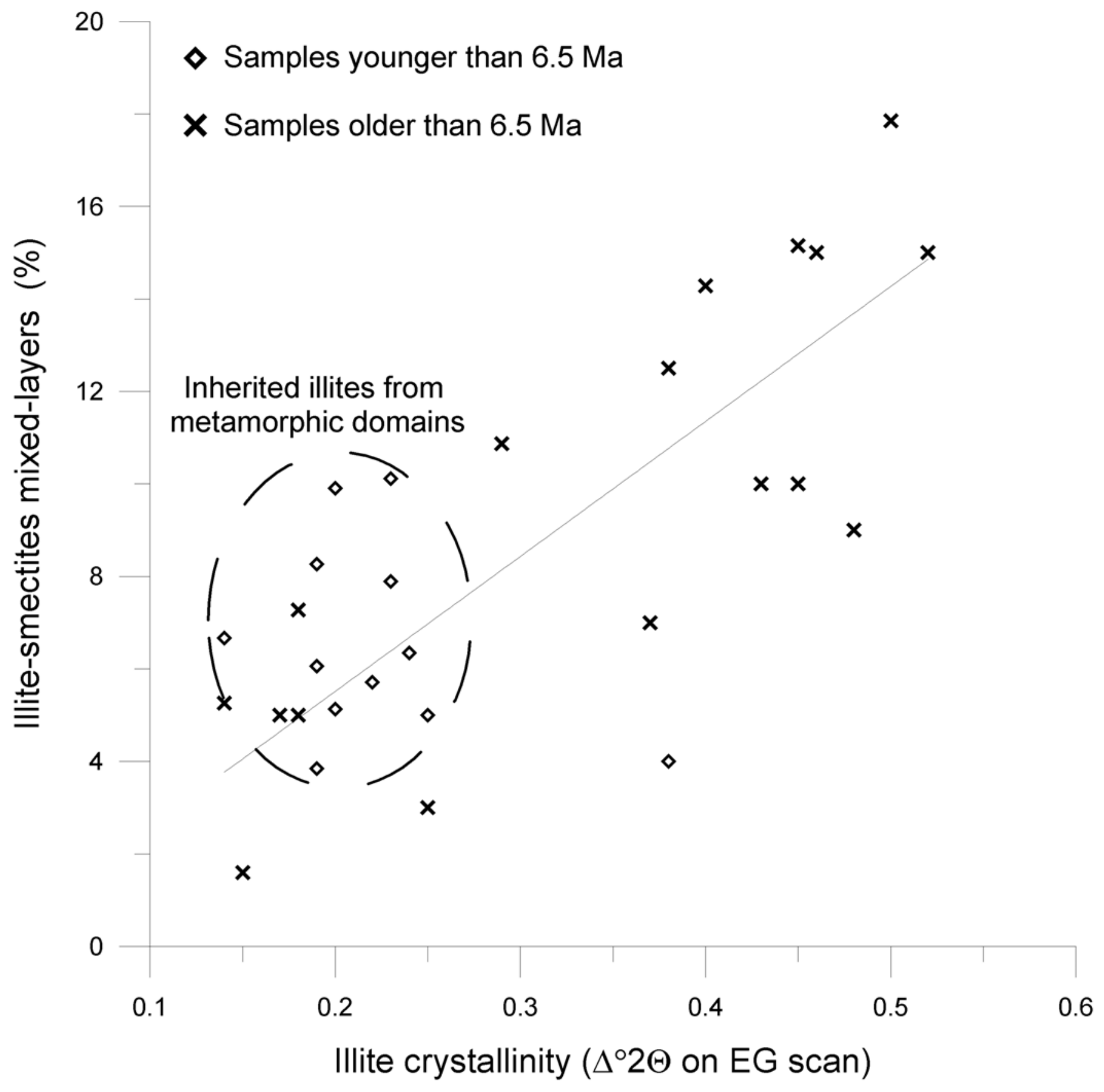

Figure 4 


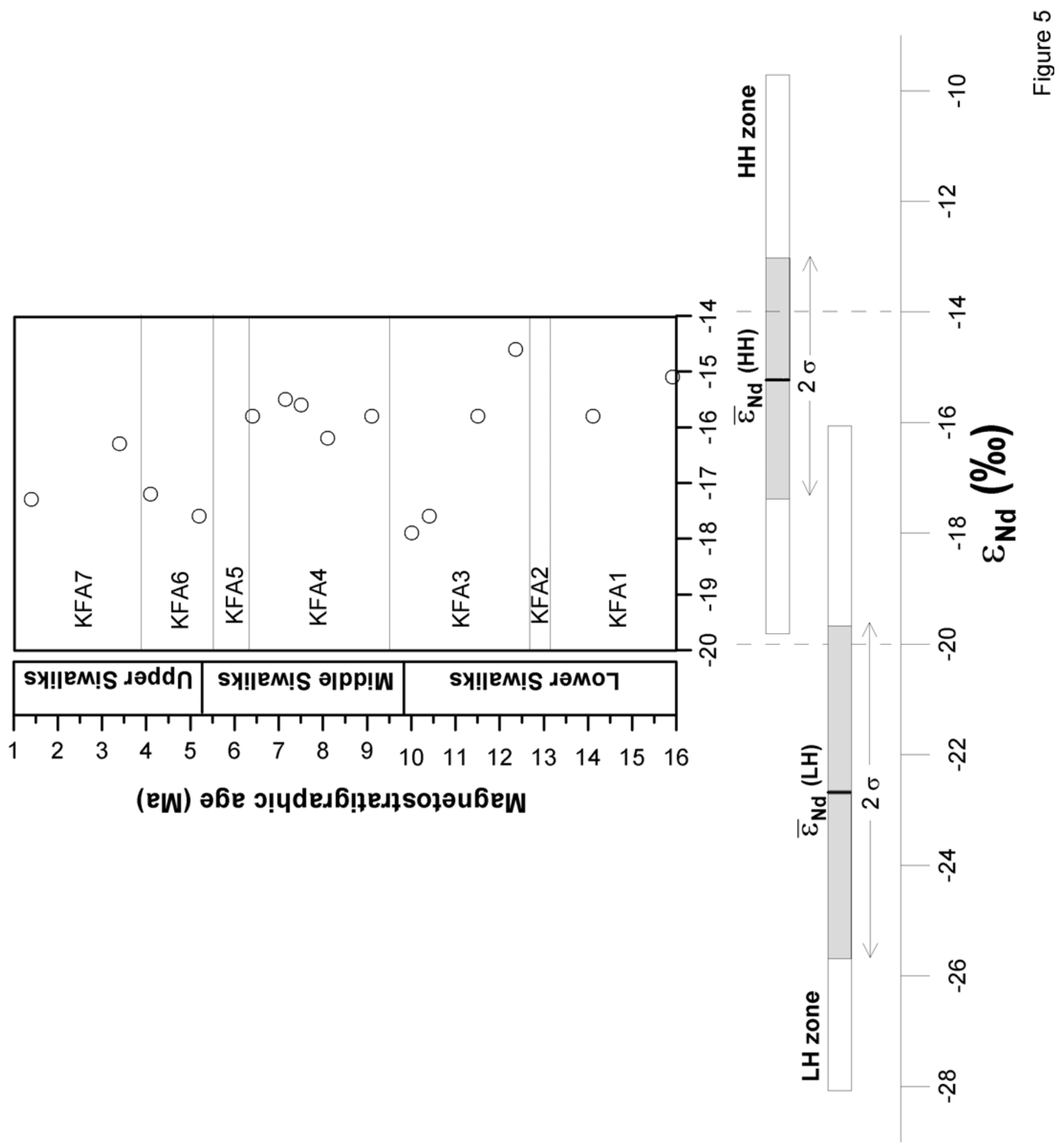




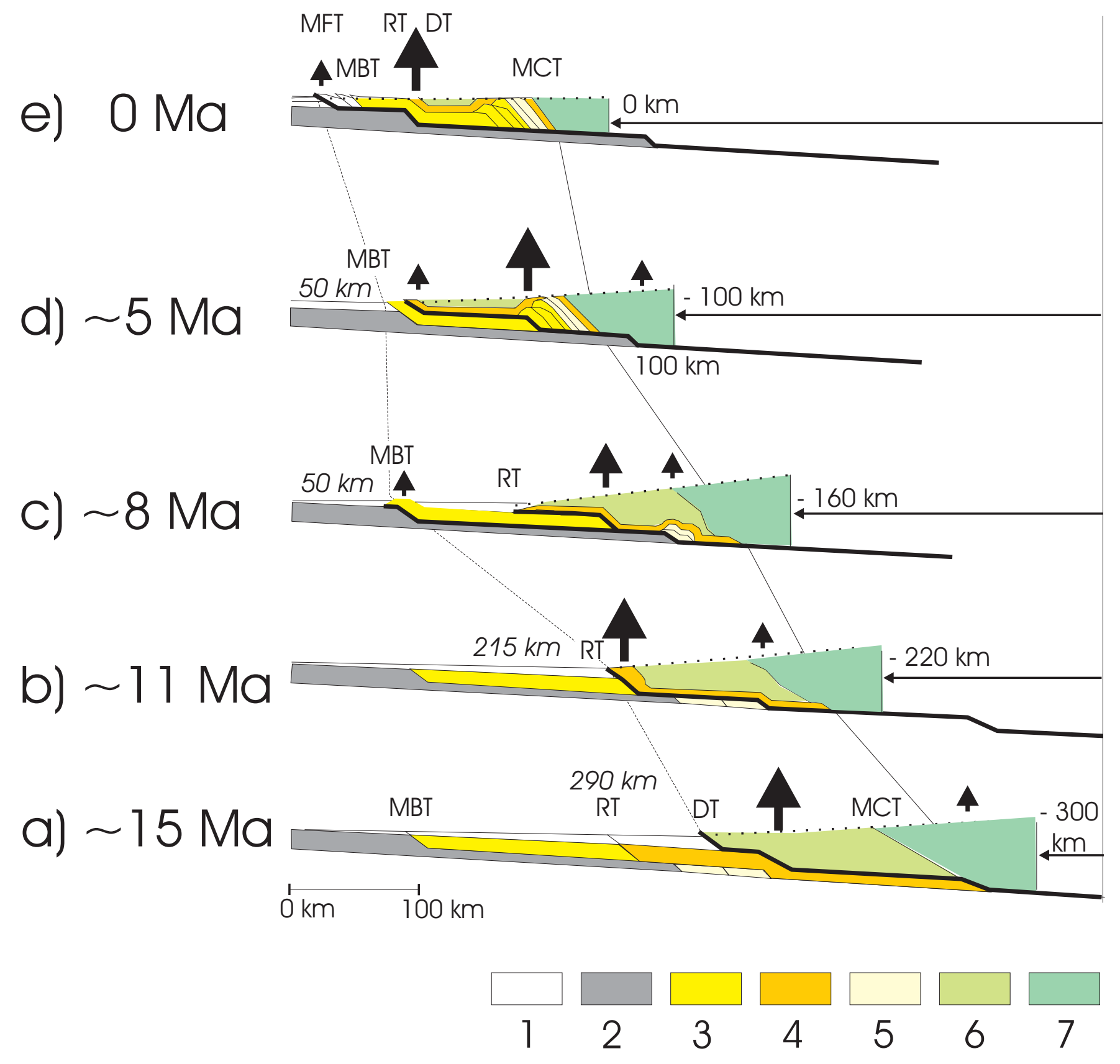

Figure 7 